\title{
骨軟部腫瘍の動注療法におけるリザーバーの使用経験
}

\author{
福岡大学医学部整形外科教室 \\ 諫 山照 刀・葉泉 \\ 城島宏・内田洋子
}

\section{Implantable Injection Port in Malignant Bone and Soft Tissue Tumors}

by

Teruto Isayama, Sansen Yoh, Hiroshi Johjima and Yohko Uchida

Department of Orthopaedic Surgery

Fukuoka University School of Medicine, Fukuoka, Japan

An implantable injection port was utilized in the intra-arterial chemotherapy of 4 cases with malignant bone orsoft tissue tumor. No patients had complications during the perod of chemstherapy. The drug delivery system using the implantabl injection port provided a more comfortable method of therapy gdministr atron for patients with malignancy.

\section{はじめに}

我々は以前より悪性骨軟部腫瘍に対して動注療法を 行い有効な結果を得てきた ${ }^{3) 4}$. しかし，動注療法に おける欠点の一つとして，動脈に㨂管したカテーテル が体外にでているため，カテーテルの先端部が容易に 移動したり，カテーテル刺入部からの感染が生じる可 能性があった。このため, 動注期間中の数力月間は入 浴等の日常生活を制限し，カテーテル刺入部を保護し なければならなかった，さらに動注期間中は入院して いなければならず，患者の物理的心理的な負担も大き い物があった．最近この動注療法の欠点を克服するた めに，カテーテル終末部にリザーバーを連結し，この 動注療法用システム全体を皮下に埋没する方法が上皮 性腫瘍で使用されてきた ${ }^{122)}$

今回我々はこのリザーバーシステムを骨軟部腫瘍に 使用し極めて有用であったので報告する。

\section{方法}

カテーテルとリザーバー設置の実際的手技は従来の 動脈捙管と大差ない。我々はカテーテルはアンスロン
カテーテル〔東レ社製〕を使い，リザーバーとしては Port-A-cath（ファルマシア社製）を使っている（図 1 ). 先ず目的とする動脈を外科的に直接露出させ, 動脈本幹に沿って剥離してその分枝を出す．分枝の末 梢側に糸をかけて結び，本幹にはテープをかけておく. 分枝の本幹接続部に糸をかけて分枝部に外套型穿刺針 を入れ分枝部から動脈本幹内へとカテーテルを挿入す る. 挿入後透視下でカテーテル先端部の位置を決める. カテーテル先端部の位置が決定されたら，分枝部と本 幹との部分にかけていた系を結びカテーテル自体を含 めて固定する. 次にリザーバー設置部位を切開し皮下 を十分に広げる。ペアンを使ってカテーテル挿入部と 皮下で連結するように剥離する。カカテテルをリザー バー設置部位に皮下を通し連結させ，皮膚を縫合して， 全システムを皮下に埋没させる（図 2)。動脈注入は 注入用の針で皮膚の上からリザーバー内に刺入させて 逆流を確認して行う。カテーテル，リザーバー維持の 為に定期的処置として，週に1回へパリン 1000 単位 でカテーテルとリザーバー内を充填させている.

また薬剤の動注終了後は蒸留水で十分にカテーテル とリザーバー内を洗浄した後にヘパリンで充填させる 


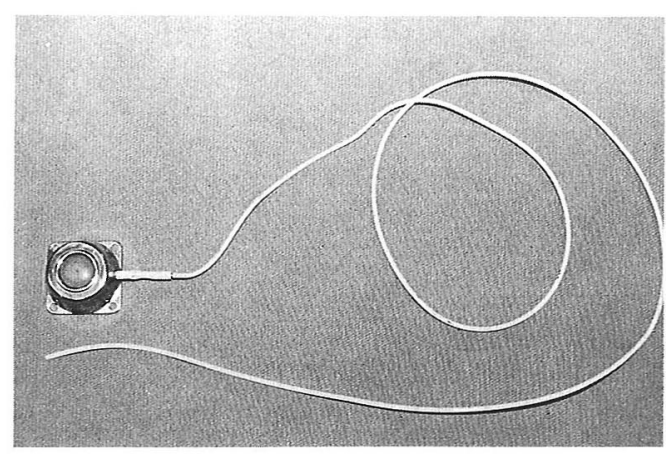

図1 我々が使用しているアンスロンカテーテル〔東 レ社製】とリザーバーである Port-A-cath（ファ ルマシア社製）である.

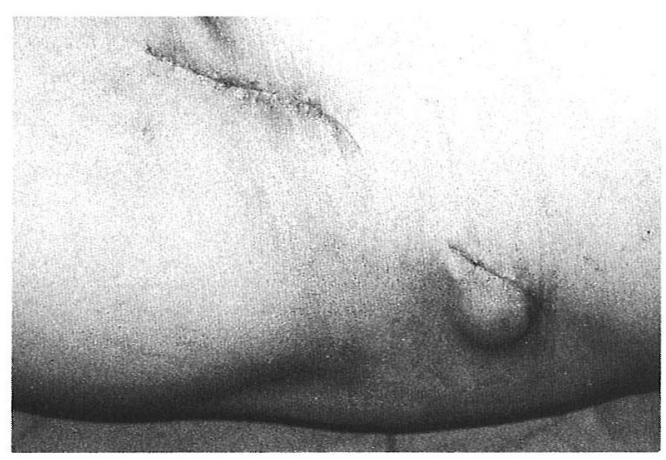

図 2 全システムが皮下に埋没した状態.
ようにしている.

\section{対象と結果}

この様なリザーバーを使用した症例は表 1 の如く 4 例で, その内訳は骨腫瘍 1 例, 軟部腫瘍 2 例, 骨腫瘍 の軟部再発例 1 例である. 症例 4 は他施設にて摘出術 を受け，その後追加手術及び化学療法を当科で受けた 例であった，動注は術前投与のみが 1 例, 術後投与の みが 1 例で, 術前術後投与は 2 例であった.

症例 2 は術後 9 ケ月で肺転移を生じ死に至った高悪 性肉腫の例である。経過期間は 2 カ月から 11 ケ月と 短いが, 他の 3 例は無病生存中である。

表 2 は動注療法の内容であるが, カテーテルの㨂入 法は病巣の栄養動脈より逆行性挿入が 2 例, 左鎖骨下 動脈から順行性挿入が 2 例であった. 我々が現在行っ ている動注療法の基本的なプロトコールを表 3 に示す. シスプラチン (CDDP) とアドリアマイシン (ADR) とを併用し, 術前 2 クール, 術後2クール行うのを主 体としている.制癌剤の種類と量は腫瘍の性質と患者 の状態により適宜增減させている。この対象となった 4 例においても化学療法の内容はシスプラチンとアド リアマイシンとを使い 2 域は 3 クール行った。ガテー テル並びにリザーバーの留置期間は 2 カ月から 5 カ月

表 1 症例

\begin{tabular}{|c|c|c|c|c|c|c|c|}
\hline 症例 & 年齢 & 性 & 診 & 手 & 動注 & 経過期間 & 予後 \\
\hline 1 & 46 & 男 & 右肩甲骨軟骨肉腫 & Tikholf-Linberg 法 & 術前 & 11ケ月 & 無病 \\
\hline 2 & 63 & 男 & 左晅部未分化肉腫 & $\begin{array}{l}\text { 広範切除術 } \\
\text { (一部 marginal) }\end{array}$ & 術後 & 9 ケ月 & 死亡 \\
\hline 3 & 32 & 女 & $\begin{array}{l}\text { 左脛骨 MHF } \\
\text { 軟部再発 }\end{array}$ & 広範切除術 & 術前, 後 & 5 ケ月 & 無病 \\
\hline 4 & 49 & 女 & 左膝窩部明細胞肉腫 & $\begin{array}{l}\text { 摘出術 } \\
\text { 追加切除術 }\end{array}$ & $\begin{array}{c}- \\
\text { 術前, 後 }\end{array}$ & $\begin{array}{l}4 \text { ケ月 } \\
2 \text { ケ月 }\end{array}$ & 無病 \\
\hline
\end{tabular}

表 2 動注方法

\begin{tabular}{|c|c|c|c|c|c|c|c|c|}
\hline \multirow{2}{*}{ 症例 } & \multirow{2}{*}{ カテーテル刺入部位 } & \multirow{2}{*}{ 挿入方向 } & \multirow{2}{*}{ 留置部位 } & \multicolumn{2}{|c|}{ 動脈注入療法 } & \multirow{2}{*}{ 使用薬剤 } & \multirow{2}{*}{ 留置期間 } & \multirow{2}{*}{ 合併症 } \\
\hline & & & & 術前 & 術後 & & & \\
\hline 1 & 右上腕動脈 & 逆行性 & 右鎖骨下動脈 & 2 クール & 0 & CDDP & 3 ケ月 & 無 \\
\hline 2 & 左鎖骨下動脈 & 順行性 & 左総湯骨動脈 & 0 & 3クール & CDDP & 5 ケ月 & 無 \\
\hline 3 & 左鎖骨下動脈 & 順行性 & 左外腸骨動脈 & $2 ク ー ル$ & 1 クール & $\begin{array}{c}\text { CDDP } \\
\text { ADR }\end{array}$ & 5 ケ月 & 無 \\
\hline 4 & 左大腿動脈 & 逆行性 & 左総腸骨動脈 & 1 クール & 1 クール & $\begin{array}{c}\mathrm{CDDP} \\
\mathrm{ADR}\end{array}$ & $\begin{array}{c}2 \text { ケ月 } \\
\text { (留置中) }\end{array}$ & 無 \\
\hline
\end{tabular}


表 3 Intra-Arterial Chemotherapy

(Vincristine, Carboquone, Cisplatin, THP-Adriamycin)

* Intra-arterial or Intra-venous

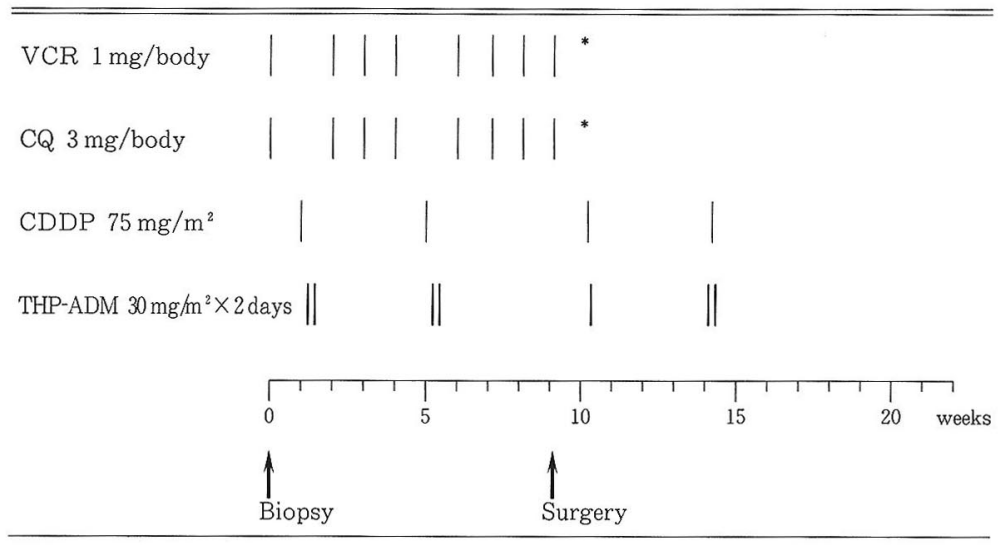

で, 留置期間中の合併症はいずれも認められなかった.

\section{考察}

リザーバーを使用することの利点は留置したカテー テルの管理を容易にすることにある，従来のカテーテ ルが体表面に出ている時には感染の危険性が極めて高 く,この部位の無菌的保護のため, 患者の日常生活に 多くの制約を加える結果となってきた、リザーバーを 使用した場合感染の危険性は従来の体表面に出ている ときに比べ著明に低下し，患者の日常生活上の不利益 はほとんどなくなった，消毒も薬剤注入時の皮膚面の 消毒だけで济むし，患者の入浴も可能で，近年重視さ れている quality of life の向上に寄与する点も極め て大きいと思われる。

これらの多くの利点に比しリザーバーの欠点は僅か ではあるもののないわけではない.リザーバーとゆう 異物を留置することによる，精神的な困惑や感染等の 合併症が認められている。リザーバー自体の故障や破 損並びにこのシステムを維持するための定期的処置を 必要とすること，さらにカテーテルの抜去や移動に際 し再度の切開が必要となることが欠点として挙げられ る。実際に我々の症例 1 において右肩のTikhoffLinberg 手術を行ったが, 術後右肩の距離が短くなっ たため，逆行性に挿管していたカテーテル先端部が中 枢へ移動し総頚動脈分岐部にまで達していた（図 3 ). このためカテーテルの位置の移動をするための切開を

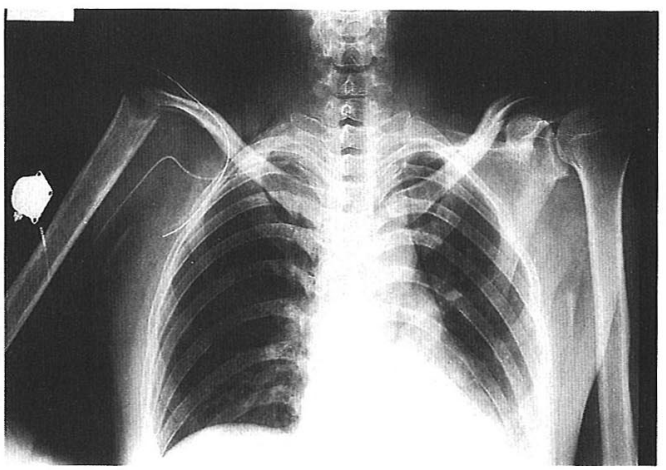

図 3 症例 1 の Tikhoff-Linberg 術後の単純レ線像で, 右肩の距離が短くり，カテーテル先端部が中枢 へ移動し総䫋動脈分岐部に達した。

必要としたが，手術的に腫瘍が広範にとれていること からカテーテルとリザーバーを抜去することとなった.

このシステムにおける合併症は我々の例では認めて いない.しかし先に述べた欠点には含まれていない面 もあるのでその対策も含めて述べる，まずリサーバー 及びカテーテルの閉塞が挙げられるが，先に述べたよ うにへパリンで定期的に充填させておくことで十分防 ぐことが出来た，次ぎに留置動脈の閉塞並びに血栓形 成が挙げられるが，これが合併中で最も重篤な状態を 呈する物である。これを予防するためには一般的には， なるべく血流が多く走行の長くない血管に留置し，血 管壁を損傷しないように愛護的に操作し, 薬骩注入後 の蒸留水によるカテーテルと留置血管内の洗浄を行う 

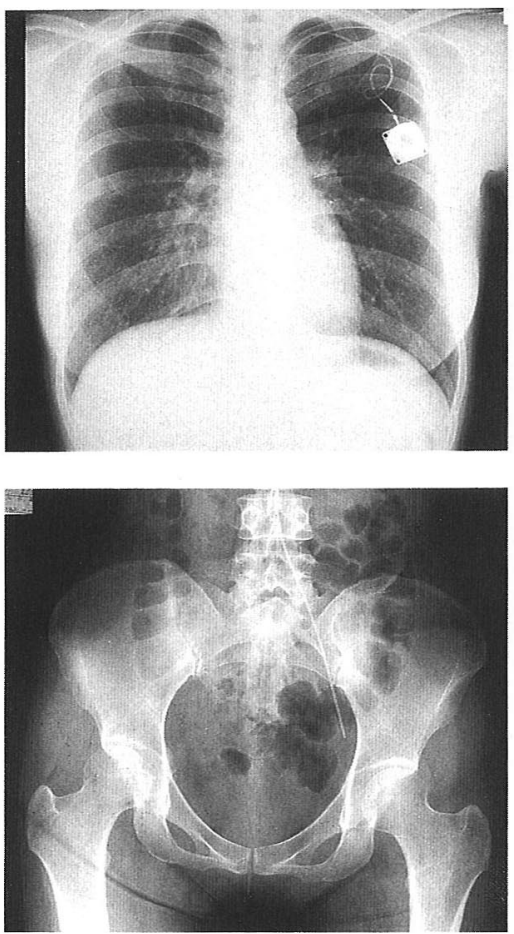

図 4 症例 3 の左鎖骨下動脈から大動脈を通り，外腸 骨動脈にまで達する長いカテーテル。

ことである．我々は症例 2 及び 3 の様な左鎖骨下動脈 から大動脈を通り, 外腸骨動脈まで達する長い㨂管 （図４）は避け，なるべく必要最短の挿管が望ましい と考えている. 次ぎに留置カテーテルの先端位置の移 動があるが，僅かな移動でも時にカテーテル先端が動 脈分岐部入口部に一致してしまい，このため薬剤が選 択的にその分岐部からの小動脈に流入し，その支配領 域に壞死などの重篤な合併症を呈することがある。こ のため留置時のカテーテル先端部の位置決定には，造 影剂を使って位置のみならず機能的に流出方向が予定 されている動脈に行っているかを確認することが大事 である，我々はさらに薬剤投与直前に再度造影剤を使っ て確認した上で使用している。この様な血管造影はこ のシステムを使えばリザーバーに刺入する針の大きさ だけを変える事で極めて容易に行う事が出来た．更に この血管造影を積極的に使い，動注後の化学療法効果 判定の参考にしている.
我々は動注療法には多くの利点があると考えている. しかし従来の方法では患者に対する制限が強く長期間 の投与はかなり困難が伴っていた。このリザーバーシ ステムは動注療法における多くの欠点を克服するので, 悪性骨軟部腫瘍に対する極的有効な道具の一つにな ると考えられた。

$$
\text { 結語 }
$$

(1)リザーバーを悪性骨軟部腫瘍 4 例の動注療法に使 用し，合併症はなかった。

(2)刺入針を大きくして動脈造影を容易に行い，化学 療法効果の判定の一助となる可能性が考えられた。

(3)リザーバーの使用により長期間通常に近い日常生 活を維持することができた。

(4)リザーバーシステムは悪性骨軟部腫場に対する極 めて有効な道具の一つと考えられた。

\section{参 考 文 献}

1）荒井保明ら：皮下埋め込み式りザーバー使用による動 注化学療法一瀶床 60 症例の検討と新しい薬剤投与への可 能性. 癌と化療, $12: 270-277,1985$.

2) Kemeny, M. et al.: Continuous hepatic artery infusion with an implantable pump : Problems with hepatic artery anomalies. Surgery $99: 501-504,1986$.

3）葉 山泉ら：骨靯部悪性腫瘍に対する Adriamycin 大 量間歇動注潦法とその無効例の検討。癌と化療，15： 2453-2458, 1988.

4）葉 山泉ら：骨軟部肉腫に対する術後動注化学潦法. 癌と化療, $16: 2718-2721,1989$.

質 問熊本大学 米村 慧輔

術後は動注療法ではなく，全身化療ではどうでしょ jか。

解 答福岡大学 諌山 照刀

必ずしも動注にこだわってはおりません，私共の化 学療法に対する考え方は, 転移を重視する必要のある 腫瘍については, 先生御指摘のような全身化学療法を も併用するようにしています，局所再発をくり返す中 低度悪性の腫瘍に対しては, その局所抑制効果を重視 して，動注療法を主体に行なうようにしています。 